Journal of

Language and

JLD (PRINT) ISSN 2397-2637

Discrimination

JLD (ONLINE) ISSN 2397-2645

Review

\title{
The Art of Political Storytelling: Why Stories Win Votes in Post-truth Politics \\ By P. Seargeant (2020) \\ London: Bloomsbury Academic, 272pp.
}

\author{
Reviewed by Patricia Canning
}

KEYWORDS: STORIES; POLITICS; RHETORIC

If I may start with a commonplace, as most rhetoricians tend to do: everyone loves a great story. With Seargeant's book, this is exactly what you get. Stories are a means of achieving coherence and inviting readers to think about things in a certain way. They are, as the author of The Art of Political Storytelling rightly says, 'explanatory toolkits to help us make sense of the times we're living through' (pp. 74-5). Stories are about 'turning abstract theories about the changes in the world into concrete scenarios' (p. 66), and narrative plays a 'pivotal role' in 'persuasive storytelling' (p. 6). Okay, so that was more than one commonplace. We need look no further than the title of Seargeant's book to know the currency of stories as it intertextually invokes other stories: Aristotle's Art of Poetry, Horace's Ars Poetica, Puttenham's The Arte of English Poesie, and many more besides. Of course, premodifying 'storytelling' with 'political' introduces or at least alludes to another commonplace: 'lies', or what Seargeant reminds us are otherwise known (depending on who's talking) as 'alternative facts' (p. 22). Acknowledging the irony here, the 'epistemological frenzy' (p. 22) such definitions generate is also part of the story. What something is called can determine whether or not you accept it as such. 'Contradictory truths' (p. 27), 'alternative facts',

\section{Affiliation}

Department of Humanities, Utrecht University, Netherlands. email: p.canning@uu.nl 
'falsehoods' (p. 22), 'post-truth[s]' (p. 22) or just plain 'lies' - definitions themselves are often the first sticking point in any argument. In rhetoric, we call this the point of 'stasis', of working out the point at which you disagree, in order to ensure - in Seargeant's terms - that 'you're both talking to the same purpose' (p. 29).

The 'purpose' of Seargeant's book is threefold:

[T] o show how the tools and tricks of narrative can be mastered to shape our understanding of the world. To explore how stories are structured, shared and contested. And to explain the rhetorical strategies that are used to enact them, and the language that's used to craft and narrate them. (p. 7)

The book is laid out in four parts with plenty of revisiting of earlier material (which is a thumbs up for coherence). Part I deals with 'apocalyptic politics', the title of which already tells (or frames) a story, and which could easily serve as an alternative title for the book. Within this first part, there are three chapters, all with subsections (all thoughtfully named and stories in themselves). It starts with the basic components of stories - words - and sets the scene (Chapter 1) by situating some of the keywords of 2016 in their political and social context: 'Essex girl' (p. 11), 'paranoid' and 'Brexit' (p. 12) all feature as new (or contested) dictionary entries, while Austria's entry for word of the year (p. 13) is a word so long it needs its own trailer. It is great to see that sign language and logograms feature too, with Japan's entry 'gold' featuring alongside the Deaf Association's sign of the year ('Trump', naturally; p. 13). All of these keywords tell their own story by defining the 'concerns of a culture' (p. 18), in this case, the story of the 'dumpster fire of a year' (p. 10) that 2016 really was. Chapter 2 deals with 'facts' and 'factcheckers' (p. 16) as well as a much-needed definition of 'post-truth' (from the Oxford English Dictionary), while warning that even dictionaries are not the objective truth-tellers that they are commonly perceived to be. An introduction to the role of subjectivity through understanding the importance of 'pathos' sets the scene nicely for the relevance of rhetoric and persuasion (or rather rhetoric as persuasion) that is promised throughout the book. Chapter 3, on 'popular fiction', debunks a few terms, from 'populism' and 'the people' (p. 40) to 'the elite' (p. 43), invoking the notion of otherness in contemporary arguments about immigration, for example, which situate abstract terms in their cultural milieu in very accessible and relatable ways.

Part II covers 'explanatory stories', 'what makes a good story' and 'dramatic structure', and moves towards a more formal analysis of 'story', citing Propp's model and Labov and Waletzky's notion of 'narrative' along the way. Chapter 4 opens with an ironic consideration of how an impressive range of political leaders (although not altogether impressive political 
leaders) have, more literally, tried their own hand at fiction. There is an illuminating look at how fictional stories work as 'strategic narratives' (p. 59) by helping us to 'make sense of our experiences' (p. 59) (echoing Turner 1996, here) and to get ideas across in ways that don't really make it that obvious that we are trying to get our ideas across. In that way, fiction operates as a 'distancing buffer' (McNay 2010) from which to consider or try out ideas and experiences. The chapter goes on to show in very entertaining ways how stories emulate life as well as providing - along with their authors - very serviceable metonymies for events and experiences (such as when columnist Margaret Sullivan 'argued that the incident [of Kellyanne Conway's pronouncement of "alternative facts" as opposed to just plain old "lies"] was evidence that society has now "gone full Orwell" ' (p. 65), or when Dick Cheney was referred to as Darth Vader (p. 72)). Such metonymic references are, by definition, only part of the whole story, and we bring that whole story to bear at each invocation (and so use the 'toolkit' well). Seargeant offers plenty of illuminating examples in the political arena. In Chapter 5, 'what makes a good story?', the art of rhetoric is again alluded to (but not quite explicated) in acknowledging the value of example (inductive reasoning), of proximate authorities in " 78 ), and a nice interplay between pathos and ethos. The nerd in me was delighted by the archetypal stories (pp. 79-93), and the graphs showing Vonnegut's 'story shapes' should be shown in every Proppian-fuelled classroom in the country (but mind, because there's a wee mistake on the labels on p. 86 where 'New Testament' is entered twice). There are a few examples of how these archetypal stories play out in reality, which helps to put them into perspective. And no decent foray into perspective-taking should ignore Chimamanda Ngozi Adichie's excellent take on the 'dangers of a single story', and Seargeant delivers here, too, closing the chapter with a section on 'single storyism' (p. 95). Bravo.

The final chapter in this section is about 'dramatic structure', and it develops the 'archetypal story pattern' (p. 101) by looking at the 'three act structure' of drama (p. 106). It shows how, through an 'extremely condensed synopsis of one of the most enduring and complex dramas of world literature' (that's Shakespeare's Hamlet, if you were wondering), most dramatic plays neatly fit the 'simple pattern' that 'underpins nearly all dramatic storytelling' (p. 109). Just don't tell Shakespeare that.

Part III covers 'language and rhetoric', largely through a closer analysis of style (the third canon of rhetoric). There is a focus on political campaign slogans and jingles, and Seargeant construes these as mini-stories or 'succinct little narratives' (p. 134) that operate metonymically for 'the campaign as a whole'. Seargeant claims that they 'work as stories' by 'plac[ing] 
the desire for change at their heart, and foreground the need for action to accomplish that change' (pp. 134-5). As I was reading through the examples, Hilary Clinton's 'Stronger Together' didn't seem to conform to this formula, so I was glad to see the author acknowledging its lack of fit at a later point which, in his opinion, was precisely why it had 'very little dynamism or emotional pull' (p. 135). In Chapter 8 in this section, the focus extends to words through 'a post-truth lexicon' (p. 143). We are treated to 'wooden' or 'vacuous' language (there's even a meaningless lexical-bingo game you can play on p. 145), metaphoric 'framing' (would you like your Brexit 'hard' or 'soft'?) (p. 148) and a host of euphemisms (in rhetorical parlance these are known as examples of 'litotes' or 'paradiastole' - basically, whitewashing). From children kept in immigration centres in cages (or 'boarding schools', depending on who's talking) (p. 152) to Melania Trump's jacket slogan ('I REALLY DON'T CARE, DO U?') as a dig at the press or an explication of her attitude to children in cages, depending on who you ask (p. 154), the meaning of meaning is explored, contested and explained in ways that show how language is both used to construct and reflect social attitudes (and how the blurred line between them gives rise to interesting ambiguities). The final chapter in this section looks at 'digital disinformation' and how political stories are 'spread' (p. 160). Reporting is, like politics, 'edging up to the entertainment industry' (p. 165), and as such, 'attention-hacking' has become big business. And so we have 'fake news' (p. 167), which itself follows a structural pattern (so says a Ukrainian television programme that plays 'StopFake Bingo!' with Russian news stories and spawned the original 'fake news' mantra). After tracing the etymological history of the term we arrive at - yes, you guessed it - Trump again, who wantonly dismisses 'anything he disagreed with' with the claim of 'fake news' (p. 171). But even 'fake news' has evolved from being an accusation to being its own political story (pp. 174-5).

Finally, Part IV of the book centres on 'fiction and reality', and introduces the reader to terms such as 'astroturfing' (or as we call it in Belfast, rent-a-mob) (pp. 182-3), the 'false flag' ('carrying out covert attacks against your own side in a conflict, which you then blame on an enemy in order to ... provide a pretext for ... attacking them'; p. 180) and 'crisis actors', 'role-players' called out to play 'victims of disasters' (p. 183), and who are accused of passing themselves off (or news outlets or governments are accused of passing them off) as real victims in school shootings, such as that at Sandy Hook in 2012. Conspiracy theories have their own narrative patterns and styles too, it seems. Or perhaps they are all trying to 'gaslight' us (thank you for explaining this!). Chapter 11 takes 'conspiracy politics' even further, introducing the notion of what Emmott calls 'binding' (1997),

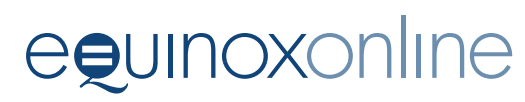


which is when, in Seargeant's terms, 'every detail included in a story automatically becomes freighted with meaning' (p. 193) precisely because it's included. Therefore, all the details of stories are picked up on and picked apart by their receivers in the search for (sometimes blind) significance, so that inconsistencies in news reports, for example, are 'taken as significant, as proof of a deliberative cover-up' (p. 198). The final chapter, 'the lie that tells the truth', considers what exactly constitutes 'truth'? It acknowledges that different domains, such as 'law, journalism, medicine' have 'different criteria for establishing whether something is factually true or not' (p. 205). Yet this is why rhetoric is so valuable as a discipline and practice. Rhetoric does not deal with 'facts' (well, not only facts; according to Aristotle, facts are the domain of scientific reasoning, not rhetorical reasoning), but rather with probabilities. Facts are widely taken to 'speak for themselves' (Perelman and Olbrechts-Tyteca 2000:17), but probabilities have to be persuasively argued. Lies, on the other hand, have to be denied or avoided. Best not to claim that Rice Krispies 'support your child's immunity' to swine flu (p. 212). Neither should you appropriate words like 'truth' in a 'strategic catachresis' (p. 214) that turns the word on its head and basically claims lies for 'truths'. Just ask The Sun newspaper, as their now infamous headline on 17 April 1989 espoused a bucketload of lies about the Hillsborough Stadium disaster and packaged them without a shred of 'evidence' (and ignoring the evidence to the contrary) as 'The Truth'. Perhaps this is best summed up in Seargeant's own words as he closes his final chapter:

[W]hen [political narrative] relies too heavily on broad generalisations, when it devolves into a one-dimensional plot that ties everything up in a neat and straightforward way, it betrays the real-life struggles of the very people it's meant to be empowering. (p. 220)

As Adichie herself says, beware the dangers of a single story.

To sum up, then, Seargeant's book is highly readable, entertaining and engaging, and it does a fine job of balancing political storytelling, context and analysis with readability and accessibility. His writing style has page-turner quality. It's sophisticated, thoughtful and razor-sharp in the humour department; indeed, there were points when I caught myself laughing out loud. I thoroughly enjoyed it from start to finish. As such, I note only one minor criticism, which is that the book does not go as deeply into rhetorical explanation as I would have expected, given the author's intention in the third aim of the book (quoted above). While some specific rhetorical strategies are presented, a lot of the rhetorical import is largely left implicit. Having said that, there are many allusions to rhetorical concepts and theories. For example, the notion of 'kairos', 'commonplaces'

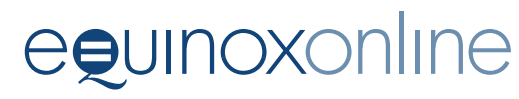


(Seargeant calls these 'shared narratives'; p. 60) and 'stasis theory' (e.g. the cognitive quandary over defining 'lies' as 'alternative stories' in Part I). An acknowledgement of the five canons of rhetoric ('invention', 'arrangement', 'style,' 'memory' and 'delivery') is made indirectly throughout the book; for example, in quoting Viet Thanh Nguyen's contention that the real 'fight' is over 'whose images will ignite the collective imagination' (p. 60), the author provides an example of the rhetorical style figure of 'energeia'. But no doubt, while the rhetorician will have fun 'term-spotting' (as I did), the upside is that the lay reader will find the book uncluttered in terms of academic terminology, and no less engaging for its absence. The rhetorical concepts, strategies, tropes and figures are there in the storytelling (with excellent and varied examples) - the book tells us that they are persuasive, just not always how. This does not detract from its readability though - it doesn't claim to be a textbook on rhetoric, after all (and Sam Leith has this all boxed up nicely in You Talkin' To Me? Rhetoric from Aristotle to Obama (2012)). But as a rhetoric teacher, it certainly offers plenty of material and thoughtful discussion for my rhetoric students, and it will definitely feature in my course next semester. And in my stylistics course. And in my forensic linguistics course. And in my friend group.

\section{References}

Emmott, C. (1997) Narrative Comprehension: A Discourse Perspective. Oxford: Clarendon Press.

Leith, S. (2012) You Talkin' to Me? Rhetoric from Aristotle to Obama. London: Profile Books.

McNay, A. (2010) Diaries of the Reader Organisation. Reader 40: 104-5.

Perelman, C. H. and Olbrechts-Tyteca, L. (2000) The New Rhetoric: A Treatise on Argumentation. Notre Dame: University of Notre Dame Press.

Turner, M. (1996) The Literary Mind: The Origins of Thought and Language. Oxford: Oxford University Press. 